\title{
Nye artikler høsten 2017
}

Rett før jul ble det satt sluttstrek for ADNO nr. 2, 2017. Denne utgaven samler alle artikler fra høsten 2017 som ikke hører til jubileumsutgaven nr. 3, 2017. ADNOs ordning med fortløpende publisering av artikler til ordinære utgaver innebærer at noen av artiklene i nr. 2 ble utgitt før jubileumsnummeret, andre etter. Til sammen består det ferdige nummeret av ni artikler som på ulike måter diskuterer problemstillinger knyttet til skole, undervisning og læring.

To av artiklene (nr.1 og 7) bygger på analyser av ulike fags læreplaner. Anja Synnøve Bakken analyserer hvordan lesing har vært forstått og omtalt i læreplaner i engelsk i et historisk perspektiv. Hun drøfter de ulike forståelsene av lesing i lys av pedagogiske strømninger og utdanningspolitiske forhold, og ser på hva de ulike forståelsene betyr for synet på lærer- og elevrollen. Hallvard Kjelen analyserer hvilken plass de grunnleggende ferdighetene har i læreplanene for henholdsvis norsk og musikk. Han finner at i læreplanen i musikk er de grunnleggende ferdighetene integrert i faget på fagets premisser, mens de har en mer dominerende rolle i læreplan for norsk.

To artikler (nr. 2 og 3) tar for seg problemstillinger knyttet til skolen som system. Kari Spernes og Hilde Sofie Fjeld studerer tospråklige faglæreres plass i skolens læringsfellesskap. Studien er basert på intervjuer med skoleledere, og søker å avdekke hvilken verdi skoleledere tillegger tospråklig fagopplæring. Artikkelen konkluderer med at selv om skoleledere uttrykker positive holdninger til å inkludere tospråklige faglærere i skolens felles planleggingsarbeid, skjer dette i liten grad i praksis. I Mette Bunting og Geir Moshuus’ artikkel er det frafall i videregående skole som er tema. Etnografiske intervjuer der ungdom i NAVsystemet forteller sine historier, er valgt som metodisk tilnærming for å belyse årsaker til frafall. Artikkelforfatterne argumenterer for viktigheten av å ta i betraktning samspillet mellom individ og system når man forsøker å identifisere årsaker til avbrutt skolegang.

Artikkel nr. 4 og 8 tar for seg fagdidaktiske problemstillinger, i henholdsvis kroppsøvingsfaget og norskfaget. Pål Lagestad presenterer en case-studie av en videregående skole i Nordland som utmerket seg ved å ha lavt fravær i kroppsøving. Artikkelen studerer hvordan denne skolen organiserte kroppsøvingsundervisningen. Funnene viser at faget ved denne skolen var kjennetegnet av høy grad av selvbestemmelse for elevene. Samtidig stilte lærerne høye krav til deltakelse, og elevene fikk tett oppfølging i et godt sosialt miljø. Margrethe Sønneland og Atle Skaftun undersøker hvordan ungdomsskoleelever opplever litterære samtaler i norskfaget, gjennom en dypstudie av en 8. klasses 
arbeid med og samtaler rundt en utvalgt tekst. Artikkelforfatterne finner at elevene setter pris på å diskutere fagspesifikke problemer på egen hånd, og de er aktive og engasjerte i arbeidet. Funnene diskuteres i lys av læringsteori om affinitetsrom.

Artikkel 5 og 6 handler på ulike måter om lærerutdanning. Torjer A. Olsen, Hilde Sollid og Åse Mette Johansen diskuterer hvilke krav og føringer til kunnskap om samiske forhold som ligger i de nasjonale forskriftene om rammeplan for lærerutdanning, og undersøker på bakgrunn av dette hvilken plass opplæring i samiske forhold har i lærerutdanningen. De drøfter hvordan lærerutdanningsmiljøer i Norge kan organisere opplæringen i samiske forhold, slik at kunnskapen blir tilgjengelig for alle lærerstudenter. Lærerstudenters opplevelse av samspillet mellom teori og praksis i lærerutdanningen er tema for Bente Hellang og Gro-Renée Rambøs artikkel. Funnene viser at studentene ikke uten videre klarer å overføre kunnskap fra den ene arenaen til den andre. De opplever praksisarenaen som viktigere for lærerrollen enn teoriarenaen. De tenderer også til å vektlegge relasjonskompetanse mer enn fagkompetanse, og ser i liten grad sammenhengen mellom disse to kompetanseområdene.

Avslutningsvis i denne utgaven finner vi Lene Solli Fitzgerald og Anne Bergs artikkel om opptrening av lesehastighet hos barn ved hjelp av trening av øyebevegelser. Forfatterne presenterer en kvasi-eksperimentell studie der en kontrollgruppe gjennomførte et treningsprogram for stabile øyebevegelser.

Testgruppen oppnådde en signifikant økning i lesehastighet, mens det samme ikke skjedde hos kontrollgruppen. Forfatterne konkluderer med at treningsprogrammet kan være et godt supplement i leseopplæringen for barn med og uten lesevansker.

Siden forrige leder ble skrevet i oktober 2017 har vi fått enda et nytt medlem til redaksjonsrådet i ADNO: Dr. Kim Haataja fra Universitetet i Tampere.

Redaksjonsrådet har nå syv medlemmer fra norske høyere utdanningsinstitusjoner og syv fra andre nordiske land; to hver fra Danmark, Finland og Sverige, og én fra Island. Redaksjonsrådet jobber aktivt med å spre informasjon om ADNO i sine respektive land og forskningsnettverk, noe som gjør at tidsskriftet når stadig nye lesergrupper og nye potensielle forfattere. Resultatet av dette ser vi i at tidsskriftet mottar stadig flere manuskripter fra våre naboland, og vi har per i dag flere artikler på svensk og dansk i behandling.

Oslo, januar 2018

Eva Thue Vold

Ansvarlig redaktør 